\title{
Economic design of things
}

Citation for published version (APA):

Can, B. (2019). Economic design of things. In J-F. Laslier, H. Moulin, M. R. Sanver, \& W. S. Zwicker (Eds.), The Future of Economic Design: The Continuing Development of a Field as Envisioned by Its Researchers (pp. 487-493). Springer, Cham. Studies in Economic Design book series (DESI) https://doi.org/10.1007/978-3-030-18050-8_69

Document status and date:

Published: 01/01/2019

DOI:

10.1007/978-3-030-18050-8_69

Document Version:

Publisher's PDF, also known as Version of record

Document license:

Taverne

Please check the document version of this publication:

- A submitted manuscript is the version of the article upon submission and before peer-review. There can be important differences between the submitted version and the official published version of record.

People interested in the research are advised to contact the author for the final version of the publication, or visit the DOI to the publisher's website.

- The final author version and the galley proof are versions of the publication after peer review.

- The final published version features the final layout of the paper including the volume, issue and page numbers.

Link to publication

\footnotetext{
General rights rights.

- You may freely distribute the URL identifying the publication in the public portal. please follow below link for the End User Agreement:

www.umlib.nl/taverne-license

Take down policy

If you believe that this document breaches copyright please contact us at:

repository@maastrichtuniversity.nl

providing details and we will investigate your claim.
}

Copyright and moral rights for the publications made accessible in the public portal are retained by the authors and/or other copyright owners and it is a condition of accessing publications that users recognise and abide by the legal requirements associated with these

- Users may download and print one copy of any publication from the public portal for the purpose of private study or research.

- You may not further distribute the material or use it for any profit-making activity or commercial gain

If the publication is distributed under the terms of Article $25 \mathrm{fa}$ of the Dutch Copyright Act, indicated by the "Taverne" license above, 


\title{
Economic Design of Things
}

\author{
Citation for published version (APA):
}

Can, B. (2017). Economic Design of Things. Maastricht University, Graduate School of Business and Economics. GSBE Research Memoranda No. 028 https://doi.org/10.26481/umagsb.2017028

Document status and date:

Published: 13/11/2017

DOI:

10.26481/umagsb.2017028

Document Version:

Publisher's PDF, also known as Version of record

\section{Please check the document version of this publication:}

- A submitted manuscript is the version of the article upon submission and before peer-review. There can be important differences between the submitted version and the official published version of record.

People interested in the research are advised to contact the author for the final version of the publication, or visit the DOI to the publisher's website.

- The final author version and the galley proof are versions of the publication after peer review.

- The final published version features the final layout of the paper including the volume, issue and page numbers.

Link to publication

\footnotetext{
General rights rights.

- You may freely distribute the URL identifying the publication in the public portal. please follow below link for the End User Agreement:

www.umlib.nl/taverne-license

Take down policy

If you believe that this document breaches copyright please contact us at:

repository@maastrichtuniversity.nl

providing details and we will investigate your claim.
}

Copyright and moral rights for the publications made accessible in the public portal are retained by the authors and/or other copyright owners and it is a condition of accessing publications that users recognise and abide by the legal requirements associated with these

- Users may download and print one copy of any publication from the public portal for the purpose of private study or research.

- You may not further distribute the material or use it for any profit-making activity or commercial gain

If the publication is distributed under the terms of Article 25fa of the Dutch Copyright Act, indicated by the "Taverne" license above, 


\title{
Maastricht University
}

\author{
Burak Can
}

Economic Design of Things

$\mathrm{RM} / 17 / 028$

\section{GSBE}

Maastricht University School of Business and Economics

Graduate School of Business and Economics

P.O Box 616

NL- 6200 MD Maastricht

The Netherlands 


\title{
Economic Design of Things
}

\author{
Burak Can*
}

September 21, 2017

\begin{abstract}
Economics is a social science, so is economic design as a field. This short article discusses, in particular, the future of economic design, and of economic theory in general. By suggesting some examples, I hope to convince the readers that the recent technological advances in science and technology will not only be disruptive to the social machinery that surrounds us but also to the future of economic design as a field. However, economic design, as an established field, has the potential to add value to the society by offering an axiomatic framework to the design of the future with a social sciences perspective.
\end{abstract}

${ }^{*}$ Department of Economics, School of Business and Economics, Maastricht University, P.O. Box 616, 6200 MD Maastricht, the Netherlands, e-mail: b.can@maastrichtuniversity.nl, Phone number: +3143 3883807. This work is partly financed by the Netherlands Organisation for Scientific Research (NWO) under the grant with project nr. 451-13-017 (VENI, 2014): "Policy Design in Dynamic Matching Markets". The support of the NWO, therefore, is gratefully acknowledged. 


\section{Introduction}

Economics as a scientific discipline is a study within the domain of social sciences. Therefore economic theory is about building theoretical foundations for social phenomena that we experience around us. Economic design as a theoretical subdiscipline is about analyzing, designing, implementing, or improving markets, systems, institutions, -broadly speaking any socio-economic, legal, financial platform- under which agents interact and engage in transactions that are financial or otherwise.

The rules of engagement in economic systems are based on our assumptions about agents, their payoff functions, and social norms that define what is desirable in a system. We consider agents to be utility maximizers and hence the more the cargo, the merrier. We assume that agents will be in a pursuit of happiness, whatever that concept might mean. This implies that agents would (if they could) try to manipulate and game the system ${ }^{1}$. We deal with cases involving uncertainty, risk, asymmetric information. We also worry about efficiency, and fairness in the design of our systems, along with other desirable norms in our society. We define mathematical axioms that relate to or reflect those noble notions.

The design of our systems are often axiomatic quests for finding mechanisms with normatively appealing features proposed by the economic designer, such as finding efficient, non-manipulable, fair mechanisms for a given problem with certain assumptions on agents' (humans') behavior and level of information which is available to the agents. The future of economic design, however, is not necessarily in the design of these systems under which humans interact. It is in the design of systems for phenomena that are not necessarily within the scope of social sciences. For instance:

1. The design of mechanisms under which internet of things (IoT), artificial intelligence (AI), and robots interact on platforms featuring properties desirable to these things. The design of collective decision mechanisms that can handle Big Data produced by these machines and that has Big Data as its main concern, e.g., computational complexity, aggregation via delegation, aggregation on networks, clustering algorithms etc.

2. The design of digital transaction/interaction methods with advances in digital technologies in mind, e.g., Blockchain, Ethereum and other distributed ledger technologies (DLT) and cryptocurrencies. The design of digital platform economies, under which assumptions on information structure is different than traditional systems, and agents are on a typically multi-sided network, e.g., Uber, AirBnB, App Store, Social Media.

\footnotetext{
${ }^{1}$ There is an undeniably growing literature on behavioral economics where the rationality assumption is seriously challenged, and there are other proposed concepts such as bounded rationality, altruism, reciprocity, k-level reasoning etc., which are beyond the scope of this article.
} 
These disruptive technologies will eventually lead to drastic changes in the society, and the economy, hence also in the way we design the latter. In what follows, I discuss the possible effects of these innovations on the study of economic design with some examples.

\section{Disruptive technologies and their design}

\subsection{Untraditional agents: IoT, AI, Big Data \& Robots}

IoT broadly refers to devices that connect to the internet or a network, deliver data, take actions and typically comprise of MCUs (micro controller units), sensors and actuators. These devices might also incorporate AI and can even be deployed en masse and engage in collective decision making scenarios. Types of these devices range from home appliances such as refrigerators, light bulbs, stereos to urban infrastructures such as automated streetlights, recycling sensors etc or even military applications e.g., UAVs, drones. As of 2016, there are approximately 3,4 billion people who are connected to the internet, while the number of IoT devices the same year is estimated to be 6,4 billion. The latter is estimated at least to triple (or quadriple) by $2020^{2}$. Some of the reasons for this massive boost in the deployment of IoT devices are the advances in the microchip production amazingly consistent with (Gordon) Moore's law ${ }^{3}$ that leads to decrease in costs. Hence the design of such an immense networks of IoT devices, possibly communicating with one another, and making collective decisions on what type of actions to take is an essential scientific endeavor.

One implication of the increase in the availability of cheap IoT devices is the massive increase in the size of available data. The term Big Data is used to refer to the type of data sets that are so large or complex that traditional data processing application software is inadequate to deal with ${ }^{4}$. Imagine an agricultural application where tens of thousands of sensors are deployed on a field to measure certain characteristics of the soil. One typical problem in these applications occur when sensors go out of calibration. It is therefore imperative for the user to decide which sensor is facing such a problem and clean the raw data by removing the input from this particular sensor. However with the advances in AI, Machine Learning and connectivity capabilities, it is now possible to let the devices do the job. The sensors can find out which "fellow" sensor in the network is not working well, and then decide "collectively" to shut down this sensor in order to produce a somewhat clean data. The devices can even aggregate their own data based on location, day, season etc and produce already processed data so as to decrease the workload of the researcher doing his $\mathrm{PhD}$ in agricultural sciences.

\footnotetext{
${ }^{2}$ See http://www.internetlivestats.com/internet-users and http://www.gartner.com/newsroom/ id/3165317.

${ }^{3}$ (Gordon) Moore's law is the observation that the number of transistors in a dense integrated circuit doubles approximately every two years. The original paper in 1965 can be also be found at Moore (1998).

${ }^{4}$ https://en.wikipedia.org/wiki/Big_data.
} 
In parallel to the development in IoT devices and Big Data, there is an increase in the automation in production, and a shift from human employment to robotics in many traditional occupations. Acemoglu and Restrepo (2017) show negative effects of robots on employment and wages depending on the exposure to robotics in different zones. Frey and Osborne (2017) study the probability of computerisation for 702 detailed occupations. Some jobs are already being taken by robots and AI, and the job security in different occupations depend on how exposed the jobs are to automation. The issue is actually so critical that AliBaba founder and chairman Jack Ma warns of "decades of pain" referring to job disruptions that would be created by automation and the internet and asks for educational reform (Solon, 2017).

The analysis of all the aforementioned technological advancements from socio-economic, legal, and ethical perspectives falls within the scope of economic design. The design of coordination and communication between IoT devices, and the design of hierarchical frameworks for interaction between $\operatorname{robots}^{5}$, (also between humans and robots) are all of possible research questions for our field. Economic design can address these problems not only from a human-agent perspective but also from a collective AI perspective, by introducing new delegation methods and layered aggregation procedures so as to efficiently deal with the computational complexity issues that come along with the Big Data. In the latter, a combination of tools from clustering algorithms can be enhanced by axioms from economic design literature on a scenario basis. With its strong theoretical foundation, economic design has a lot to offer to the society of future via revisiting its postulates, axioms, and theorems to analyze, design, implement, and improve systems for machines, and thereby for humans, perhaps starting from Asimov's famous three laws of robotics ${ }^{6}$.

\subsection{Untraditional markets: DLT, and (Digital) Platform Economies}

Markets are typically physical places where exchanges occur and trust is the most crucial aspect for a market and its participants to thrive. Traditionally banks serve a centralized medium for trust and binds the lender and the borrower with contracts. Distributed Ledger Technologies (DLT) changes the very structure of this centralization. As the name suggests, instead of a central ledger, such as a bank, in DLT systems, every transaction is written in decentralized ledgers that cannot be altered without predefined consensus mechanisms. Among the DLTs, Blockchain and Ethereum are the most well-known examples. The latter especially has a lot of application with practical solutions for democratic decision making procedures, participatory democracy and even possible direct democracy. There are already existing financial applications based on Ether, the cryptocurrency based on

\footnotetext{
${ }^{5}$ For some interesting applications of communication and coordination between drones while making installations such as bridges, see Augugliaro et al. (2013, 2014).

${ }^{6}$ Isaac Asimov, a scholar in chemistry by profession, was one of the first to propose robotics ethics in his famous science-fiction story series I, Robot (1950). For an interesting read on the new field "machine ethics" see Anderson and Anderson (2011).
} 
Ethereum, where people already build their own investment funds, and collectively decide (without delegating that decision power to the bankers) which start-ups they would like to support financially and invest in.

A relatively recent concept, (digital) platforms, is another important subject of interest for economic design. Platforms are essentially markets where different types of agents meet and conduct transactions. However platforms themselves are also products. To illustrate platforms, consider two simple -and rather nostalgic- examples of the concept that were actually not digital: VHS and Betamax video formats. Under these formats, movie producers and consumers were matched. The choice of platform for all agents in this multi-sided network, e.g., movie producers, consumers, movie rental shops etc., has always been an interesting game. Agents, with a sunk cost perhaps, could leave the network and go for the other platform (just like it did happen at the end of the Videotape format war and resulted in the end of Betamax). Today we have the so-called digital platforms. We have Uber, a digital platform where drivers meet passengers. We use Netflix, or Hulu (or other platforms) to watch our favorite shows and meet content producers. Even larger platforms where consumers and software developers meet are iOS AppStore and Google Play. Both of these digital platforms are massive and thick markets with multiple safe payment systems. The simplicity of smoothly buying-downloading-installing apps via these digital platforms is incomparable to that of buying software on a real store and installing them via CDs. Finally, without any real physical congestion like a store on a weekend would have, there is effectively little issue of congestion.

DLT systems, digital platforms, and cryptocurrencies potentially exhibit all the features that Roth (2015) thinks are essential for a design to work successfully. Eventually economic design will be more and more about platform design and other the design of digital technologies, platforms, and markets, with digital features they exhibit. Therefore the future of economic design lies in the ambition to be the "scientific platform" under which the designers and the implementers of digital platforms are matched.

\section{Conclusion}

As a final concluding thought, let us take a moment and ask ourselves: "why do we actually not use direct democracy?". One of the most accepted argument against direct Greek style democracy is that it is practically not possible to ask every individual their opinion on all issues in a society. However, given the possibilities with Ethereum and other digital platforms, and the advances in Machine Learning and AI, it is only a matter of time before every individual is able to choose their own AI representative and delegate collective decisions on every issue in their society to their personal AI representative, should he or she wish so. Perhaps in a few decades, parliamentary systems will completely disappear and be taken over by these machine delegation systems, -a truly digital democratic platform where 
representatives are never fraud and strictly represent individuals' perspectives. Direct democracies under AI-representation might be much more desirable also because it can, in principle, protect democracies from populism that often threaten universal values, human rights, minorities. It is possible to offer a rich and diverse set of AI softwares for representing all colors of the political spectrum, on the condition that it does not violate universally agreed principles and does not conflict with, or challenge other pre-agreed values, such as constitutions. Such changes should not be taken as science fiction. It is already happening in hedge-fund investments where AI, Big Data and Machine Learning meet, and investors are clearly better of delegating those financial decisions to machines ${ }^{7}$ rather than humans.

To sum up, the frontier of research on smart and autonomous systems has been mainly pushed by computer scientists. However, there is an urgent need in addressing the recent technological advances from a social sciences perspective, by using economic design and collaborating with psychologists, philosophers and of course computer scientists. Implementation of most technologies require an ethical foundation. In case these technologies are endowed with AI and learning capacity, these ethical, social considerations must be encoded in the intelligence of these machines. Nationwide smart electricity grid implementations, for instance, require prioritization of services and certain locations, e.g., hospitals, water systems, and public buildings. What are social, ethical, political consequences of different smart implementations? How can we build smart but also social devices, networks? How can we ensure innovation goes hand in hand with social inclusion? How can we use (digital) platforms to that end? These priorities should not depend only on concepts such as cost-efficiency but also on other values, such as fairness, neutrality, consistency etc, -the very axioms that economic design deals with.

Times are a changing, and the future has many possibilities for the mankind, some of which may be dreadful. Economic design has the potential to incorporate human values in the design of every prospect that may be created by the aforementioned disruptive technologies. A well designed prospect is always better than one unexpected and unforeseen, hence, the sooner the better that economic design starts to invest in the "economic design of things".

\footnotetext{
${ }^{7} \mathrm{AI}$ and Machine Learning based hedge funds have been outperforming quants and other traditional hedge funds in a persistent way since 2010 (Eurekahedge, 2017)
} 


\section{References}

Acemoglu, D. and P. Restrepo (2017). Robots and jobs: Evidence from US labor markets.

Anderson, M. and S. L. Anderson (2011). Machine ethics. Cambridge University Press.

Asimov, I. (1950). I, Robot. Gnome Press.

Augugliaro, F., S. Lupashin, M. Hamer, C. Male, M. Hehn, M. W. Mueller, J. S. Willmann, F. Gramazio, M. Kohler, and R. D'Andrea (2014). The flight assembled architecture installation: Cooperative construction with flying machines. IEEE Control Systems 34(4), 46-64.

Augugliaro, F., A. Mirjan, F. Gramazio, M. Kohler, and R. D'Andrea (2013). Building tensile structures with flying machines. In Intelligent Robots and Systems (IROS), 2013 IEEE/RSJ International Conference on, pp. 3487-3492. IEEE.

Eurekahedge (2017, January). Artificial intelligence: The new frontier for hedge funds. Technical report, Eurekahedge. http://www. eurekahedge.com/Research/News/1614/ Artificial-Intelligence-AI-Hedge-Fund-Index-Strategy-Profile.

Frey, C. B. and M. A. Osborne (2017). The future of employment: how susceptible are jobs to computerisation? Technological Forecasting and Social Change 114, 254-280.

Moore, G. E. (1998). Cramming more components onto integrated circuits. Proceedings of the IEEE 86(1), 82-85.

Roth, A. E. (2015). Who Gets What-and Why: The New Economics of Matchmaking and Market Design. Houghton Mifflin Harcourt.

Solon, O. (2017, Apr). Alibaba founder Jack Ma: AI will cause people 'more pain than happiness'. https://www.theguardian.com/technology/2017/apr/24/ alibaba-jack-ma-artificial-intelligence-more-pain-than-happiness. 